\title{
Stem cell stories: from bedside to bench
}

S Woods

$J$ Med Ethics 2008 34: 845-848

doi: 10.1136/jme.2007.022194

Updated information and services can be found at:

http://jme.bmj.com/content/34/12/845.full.html

These include:

References This article cites 17 articles, 5 of which can be accessed free at: http://jme.bmj.com/content/34/12/845.full.html\#ref-list-1

Email alerting Receive free email alerts when new articles cite this article. Sign up in the service box at the top right corner of the online article.

Topic collections Articles on similar topics can be found in the following collections

Ethics of reproduction (3678 articles)

Notes

To order reprints of this article go to:

http://jme.bmj.com/cgi/reprintform

To subscribe to Journal of Medical Ethics go to:

http://jme.bmj.com/subscriptions 


\section{Stem cell stories: from bedside to bench}

\section{S Woods}

Correspondence to:

Dr Simon Woods, Policy Ethics and Life Sciences Research

Centre, Newcastle University, Citygate, St James Boulevard, Newcastle upon Tyne NE1 4JH, UK; simon.woods@ncl.ac.uk

Received 31 August 2008 Accepted 3 September 2008

\section{ABSTRACT}

The stem cell story is not a simple story but a complex narrative: one that requires careful analysis in order to identify major themes and plots. This paper offers an analysis of the ethics of the clinical application of stem cells and argues that even quite risky therapies can be ethical. These arguments cannot be used to justify all aspects of contemporary stem cell science, including human embryonic stem cell science, which remains theoretical and speculative. It is argued that the homogenisation of stem cell science obscures the distinction between clinical application and experimental laboratory science in a morally problematic way.

The stem cell story tells of a limitless supply of personalised replacement body cells. No more diabetes or heart disease; no more Parkinson's disease or dementia. Indeed, some go so far as to speculate that it will be possible to regenerate virtually all body parts. ${ }^{1}$

The hope that stem cell science will prove to be a comprehensive treatment has captured the popular imagination, though some have been disquieted by the means used to achieve this utopian end. Destructive embryo research and the use of aborted tissues are repugnant to some, leading several commentators to respond that repugnance has no place in the moral evaluation of the science, ${ }^{2}$ whereas other emotions such as naive optimism for the science are equally problematic but rarely singled out for criticism. The hyperbole of hope as captured by the Korean commemorative stamp, showing a paralysed man leaping from his wheelchair, typifies the Faustian over-reaching of some stem cell advocates. ${ }^{34}$

That stem cell science is advanced as an unmitigated public good also raises questions about how such goods are defined. The "good" hovers between the clinical benefit of current technology, the hope of future benefit, and amorphous economic benefits. Each aspect adds to the obstacle of enabling "the public" to develop an informed opinion on the reality of stem cell science. Understanding stem cells is a challenge, as the sources of information are also part of the problem: overhyped media reports, ${ }^{45}$ overenthusiastic critical commentary ${ }^{6}$ and the unfortunate history of science conducted in secret, which casts a shadow over contemporary science policy and practice.

The stem cell story is a complex tale. This paper unpicks some of the complexities and identifies some of the ethical challenges to be addressed. The paper begins with an analysis of the ethics of the clinical application of stem cells and argues that even quite risky therapies can be ethical. These arguments cannot, however, be used to justify all aspects of stem cell science, and in particular human embryonic stem (hES) cell science, which remains theoretical and speculative. It is argued that bringing together all aspects of stem cell science under one rubric homogenises the field but obscures important moral distinctions between clinical application and experimental laboratory science.

\section{STEM CELLS AS THERAPY}

The stem cell dream is a partial reality; many patients have survived intensive chemoradiotherapy by rescue with blood stem cells through either bone marrow transplantation or (peripheral) blood stem cell transplants. In the 60-year history of bone marrow transplantation, leukaemia has changed from being an almost universally fatal disease to a disease permitting long-term survival. It is therefore a just source of hope that future applications of stem cells may work for a range of conditions; it is also an important validation that stem cells do have clinical application. Hence, part of the stem cell story concerns the ways in which they have become what Thompson and others ${ }^{8}$ describe as "promissory matter"-entities endowed with hope and expectation for future possibilities.

Cancer is a serious disease and the application of clinical and scientific knowledge to its amelioration and cure is a good to be universally endorsed. However the clinical success of stem cell therapy cannot serve as a moral OED in the complex terrain of stem cell science. The history of bone marrow transplantation is not one of unqualified success, as there are still significant scientific and ethical challenges to be faced. However the intuition that it is right to strive against a serious human harm can only be a starting point in what requires a considered and detailed moral evaluation. The success of using blood stem cells to treat serious disease provides a clear context in the justificatory framework upon which contemporary stem cell science draws. This framework harks back to one of the earliest aspirations of medicine, to discover the panacea. It is only relatively recently in the history of medicine that clinical medicine has become consistently successful in treating disease. ${ }^{10}$ The treatment of cancer is again a case in point, where the goal of curing cancer has been pursued with the awareness of the risk that the treatment may be as likely to harm or kill the patient as the disease. Bone marrow transplantation was developed as much as a means of rescuing a patient from iatrogenesis as it was a means of providing a disease-free transplant "organ". ${ }^{11}$

\section{ETHICAL UNDERPINNINGS}

Consequentialist reasoning in the form of riskbenefit evaluation has been a mainstay of clinical 
medicine. Faced with an adult with acute leukaemia, it is reasonable and just to treat the patient even when there is a risk of serious harm, because what is at stake, inevitable death without treatment, is so serious an outcome-although since tissue-typing, prophylactic and supportive therapies have improved, blood stem cells have become routine therapies. ${ }^{12}$

Reflecting upon the ethical aspects of bone marrow transplantation, one can see that (at least) four familiar areas of medical ethics are engaged: autonomy, beneficence, the sanctity of life and instrumentalism. Autonomy, because even where patients are well informed of the risks and chances of benefit, they are often willing and eager to take the risks of treatment but, should they so wish, to refuse that treatment even if death will be the result. Beneficence is engaged because the aim of the treatment is to achieve a major good for the patient-cure or long-term remission from a potentially fatal disease-and for a wider population of patients to do good by further proving the principle of benefit. The sanctity of life is engaged because it is accepted that a risk of death as an unintended side effect of a treatment given with the intention of saving life is a moral norm of medicine. Instrumentalism is also engaged if the procedure is in any way experimental, as in a clinical trial. Instrumental use of others is regarded as permissible if this is the only proportionate means to achieve an important good. ${ }^{i}$

Autonomy, beneficence, sanctity of life and instrumentalism are also familiar leitmotifs within the stem cell story. The question for consideration here is whether the argument for using risky but established stem cell therapies has any role in the moral justification of future but as yet theoretical therapies. I suggest not, since novel stem cell research is conducted on quite different territories and includes diverse sources of cells: cord blood, somatic tissues, and human and hybrid embryos. My point is that the ethical reasoning that seems so robust in the context of the actual clinical application of stem cell therapies becomes attenuated and overshadowed by other important considerations in the more esoteric context of hES cell research.

Returning to blood stem cells; the proximity of a gravely ill patient to a risky but potentially beneficial therapy provides a moral rationale for using the therapy. This model of justification has become a routinised part of ethical clinical judgement. Autologous (self) transplant is a particularly strong case; here the risks are borne by the individual patient who is also the person who has most to lose. The case becomes more complex when considering allogeneic (donor) transplantation.

One of the limitations of autologous transplantation is the risk of reinfusing the disease the procedure aims to treat, reintroducing cancer stem cells along with the blood stem cells. Using stem cells from a healthy donor avoids this problem, but now it is necessary to consider the welfare and interests of other individuals who would otherwise be at no physical risk but for their willingness to act as donors. There are of course moral complexities associated with live donation of any kind, but the broader question of whether it is right to place healthy donors at risk of harm has been resolved, in the routine instances where the procedure is proven to be successful. blood stem cell donation is a beneficent act, likely to achieve a major good for a proportionately small risk of harm, and so long as the donor's autonomy is respected and welfare safeguarded, donation is regarded as a justified form of instrumentalism.

\footnotetext{
${ }^{\mathrm{i}}$ The instrumental use of others in medical science is clearly subject to the Declaration of Helsinki caveat that the interests of the individual are above the interests of science and society.
}

For the recipient of a donor transplant, there is an additional risk from a potentially fatal form of immune-response, graftversus-host disease. ${ }^{13}$ So regarding the ethical justification for using a form of treatment with this particular risk, there is further need to calculate the risks and benefits and to enable the patient to make an informed decision. An early and abiding challenge in the clinical application of stem cell therapies is, therefore, to understand the science behind the phenomenon, using this knowledge to seek new and safer sources of stem cells. Hence, one of the important aspirations for hES cells is lowering the risk of a serious immune response and thereby overcoming one of the most serious limitations to current clinical applications.

\section{SEEKING NEW TERRITORY: STEM CELLS AND EMBRYOS}

The search for sources of stem cells is where the stem cell story becomes entwined with other epics of modern medicine: in vitro fertilisation (IVF) and abortion.

IVF and the science of embryology that underpins it have evolved techniques enabling the genetic analysis of the embryo before implantation. Preimplantation genetic diagnosis (PGD) also provides the means of selecting a sibling as a source of tissue-matched fetal stem cells and bone marrow for an existing and afflicted child. In the UK, the Human Fertility and Embryology Authority (HFEA) have deliberated on a number of instances in which a case has been made for using a combination of IVF, PGD and embryo tissue typing. ${ }^{14}$ The complex scenario of the so-called "saviour sibling" engages with some of the same ethical concerns as for bone marrow transplantation, but there can be no simple transposition of one case to the other. Apparent in the testimony of families and clinicians are the emotional and moral tensions involved. ${ }^{15}$ This is not simply the case of sick patients deciding whether to undergo a potentially beneficial treatment in which they are the main risk bearer. The exposure of a normally fertile woman to the not inconsiderable risks of IVF, the creation and instrumental use of a child that need not have been created through IVF, and the probable destruction of surplus embryos create a complex moral scenario. Add to this the risks to both donor and recipient of the transplant procedure and the uncertainty as to the future welfare of both, in circumstances in which the interests and welfare of a family unit are inextricably linked, then it becomes a difference in kind from "ordinary" bone marrow transplantation.

Despite the differences, a clinical ethical case can still be made for sibling donors, premised upon the strong possibility of providing real benefit to an existing individual in circumstances in which there is a growing body of evidence of the benefits and risks of the procedure. However, a further twist to this success story is the now flourishing industry that surrounds cord blood banking. The principle of fetal stem cell transplantation is sufficiently understood in the public domain for it to have become a focus of speculative commercial venture by banking cord blood as an insurance policy against future need. The Virgin Health Bank (http://www.virginhealthbank.co.uk/), for example, appeals both to altruism (a public bank in which potential benefits are shared) and to self-interest (a plan in which one's child has a personal insurance policy guaranteeing future use of stem cells).

Clinical "waste" hence becomes a future insurance, sold with the rhetoric of certain benefit and drawing upon the future promise of stem cell science but with no strong evidence that individual donors are likely to need or would in fact benefit from their "deposit". This is but one more example of the 
deliberate homogenisation of stem cells, which blurs the boundary between the proven clinical benefits of blood stem cells and the still highly experimental status of hES cells. This blurring of boundaries is problematic in two ways: for individuals who are approached to contribute to research through tissue donation, and for the wider citizenry who are required to both understand and approve national programmes of research.

\section{MORAL STATUS AND TISSUE ECONOMIES}

Stem cells as such have no intrinsic moral value, but the progenitors of stem cells do. However, most ethical concerns are satisfied, at least in adult donation, so long as the donation is a free and informed, autonomous decision. Significantly, an important component of what informs the bone marrow transplantation donor is the high likelihood that the donation will benefit an existing patient. Blood stem cells are exemplars of the promissory future of hES cells; however, the further away from clinical application and the more complex the networks of exchanges between progenitor and recipient, the more difficult it becomes to equate blood stem cells and hES cells.

In contrast to blood stem cells, hES cells are not donated directly nor are they currently donated for the immediate therapeutic application, although this is a matter of some misunderstanding by those approached to donate tissue for research. hES cells are rather created by scientists from donated eggs and embryos for the purposes of theoretical research. Hence, the question of hES cells engages the issue of moral status, because they may be obtained only by the destruction of human embryos, which are regarded by some as having a moral value significant to the debate, although the point is disputed. ${ }^{16}$ I do not wish to pursue this dispute here, but rather wish to raise a different question of value. Both blood and embryonic stem cells, like many other human tissues, are regarded as "precious" by those who need, use and exchange them. ${ }^{17-21}$ Of course, precious, like many value terms, is conveniently ambiguous between notions of monetary value, instrumental value and intrinsic value. There is no doubt that some human tissues (eggs, embryos and fetuses) are regarded as valuable for their relative scarcity. But the ambiguity around the term precious allows further ambiguity about the "value" of these tissues. This ambiguity is, paradoxically, accompanied by a deliberate ambivalence regarding status and value, particularly when it is necessary to justify the procurement and use of tissues in controversial circumstances. By diminishing the "value", in all senses of the term, it strengthens the case for putting them to alternative use. One of the earliest examples of the diminishment of value is the "argument from waste", which legitimises the procurement and use of human tissue that would otherwise be disposed of.

\section{THE ARGUMENT FROM WASTE}

John Rock, an early pioneer of IVF research, rationalised his strategy of seeking embryos in the organs removed at hysterectomy by arguing that the procedure was clinically necessary and that the tissues, embryo and all, would normally be incinerated. ${ }^{20}$ The idea that this was merely judicious use of waste is belied by Rock's elaborate preoperative preparation of these women, timing the surgery to occur immediately after the woman's most fertile period and encouraging sexual intercourse to increase the probability of pregnancy at the time of surgery. There is no doubt that the discovery of early human embryos was a prize valued by Rock and colleagues, who did not consider their actions parallel to surgical abortion..$^{20}$ It remains an open question to this day just how well informed these patients were of Rock's intentions, although there is no question that they were very well cared for; receiving free treatment from a recognised expert. ${ }^{\text {ii }}$ This exchange of "surgical waste" for expert services is but one example of the kind of complex exchange that makes up the expanding tissue economy. The paradox is that terms denoting low or no value, such as waste, surplus and spare are so frequently used to describe material that, once obtained, becomes of significant future value. These were some of the issues in dispute in the now infamous case of Moore $v$ The Regents of the University of California, in which a patient, while endeavouring to be rid of his disease, became also the uninformed source of tissues for a potentially profitable commercial venture..$^{21}$

The quest for new tissues with research potential presents quite different challenges for the issues of autonomy, beneficence, instrumentalism and the sanctity of life and marks a significant distinction between tissues obtained for research and those obtained for therapeutic purposes.

Postimplantation tissues obtained after abortion are also a source of stem cells. In England, women are unlikely to be informed of the exact uses of their tissues. ${ }^{18} 22$ Naomi Pfeffer ${ }^{23}$ reports the views of women undergoing termination of pregnancy, confirming that women invited to donate their tissue for research know little of the purpose of such research. Pfeffer's work reveals that once the women had a better understanding of stem cell research and its ambition to create "immortal" cell lines, they found this use of their tissue troubling, because of "its apparent capacity to somehow reinstate and even develop the fetus's physical existence and social biography beyond abortion, the very thing abortion is meant to eliminate" (p2553). ${ }^{23}$ The situation in England that prevents women from exercising their discretion through consent is due to the abiding influence of the 1989 Polkinghorne guidelines. ${ }^{24}$ These Department of Health regulations were designed to prevent women deliberately conceiving in order to be donors of tissue, such as fetal neural stem cells, for an ailing relative or for a particular research purpose.

The use of postimplantation tissues makes a notable contrast to that of preimplantation tissues, where women undergoing IVF create embryos knowing that a proportion of them will be donated to stem cell research. While the preimplantation donors are on the face of it much better informed, empirical work in the field is disclosing interesting data regarding donors, attitudes towards their embryos. ${ }^{19}{ }^{25}$ What is yet to be explored is whether donors have later reason to regret their decision in the light of a failed IVF treatment, knowing that their "other" embryos exist as immortal cell lines or as possible future children. ${ }^{26}$ Women invited to donate embryos and eggs for stem cell research are in a complex and potentially vulnerable position. ${ }^{19} 25$

Eggs, embryos and other tissues, bought and sold for cash or benefit in kind, are valuable tokens of exchange in a thriving tissue economy. As Jasanoff ${ }^{27}$ has convincingly argued, there is a real global economy of human tissue, which adds further complexity to the stem cell story. For individual actors within this market, it is unclear whether one must abide by the full

\footnotetext{
ii While it may be inappropriate to apply contemporary standards of informed consent to Rock's work it nevertheless raises issues resonant in contemporary contexts in which, for example, embryo donors are not straightforwardly autonomous, informed, altruists.
} 
rules of commerce or whether there are constraints on both buyer and seller of altruism and public spiritedness.

The stem cell story is not a singular story, but a complex tale playing to important human aspirations and vulnerabilities. The homogenisation of stem cells, which blurs the distinction between current proven clinical application of stem cells and the highly experimental and speculative nature of hES cell research, is one of the challenges in the ethics of stem cell research. Without this separation, it is impossible for citizens and policymakers to distinguish the social and ethical complexities of the story. The admixture of commercial speculation and appeal to human altruism transforms the donation, storage and exchange of human tissues into a complex tissue economy in which individuals are asked to play patient, donor and speculator. Scientific ambition, real clinical need and the prospect of commercial benefit are just some of the subplots that add to the complexity. There are also other significant social and ethical issues at stake: instrumental use of humans, commodification of the body and continuing challenge to the ontological status of the "human".

One area of hES cell research has the merit of scientific and moral honesty. Research utilising the "cytoplasmic hybrid embryo" 28 has caused great public controversy, yet at second glance has much to recommend it. The cytoplasmic hybrid embryo is created by transferring human genetic material into an enucleated animal egg, with the resulting "embryo" used as a source of hES cells for research purposes. The hybrid embryo is regulated as for any human embryo and cannot be kept beyond 14 days of development, although in all likelihood it could not survive beyond this time (Dr Lyle Armstrong, Newcastle University, personal communication).

The issue of creating cytoplasmic hybrids is seen by some as challenging the very nature of what it is to be human. ${ }^{29}$ Yet the work has important merits, enabling scientists to understand and improve upon current techniques of cell nuclear transfer, study the genetic basis of disease, lay the foundations for future cell based therapies and test novel drugs with the need for fewer animal experiments. In addition, there are three further aspects of hybrid research to note. The first is that the research is very clear about the experimental nature of embryonic stem cell research, representing a step back for scientists, who have acknowledged the need to study further the basic techniques and mechanisms of producing hES cell lines. The second is that it emphasises the gap between clinical applications of, for example, blood stem cells and the speculative use of embryonic stem cells in therapy. Third the hybrid research can operate at a clear remove from the IVF clinic with its potential for the exploitation of the donors of human eggs and embryos.

\section{CONCLUSIONS}

The stem cell story is far from finished and this paper has only touched upon the moral complexity of the tale. The therapeutic use of certain kinds of stem cell has become established, and, as I have argued, the moral case for their use has been routinised. However, there must be separation between what is currently possible and what is merely speculated. Human embryonic stem cells remain experimental and still require major programmes of basic science before their potential can be applied. Moreover, the research programmes for hES cell require the use of human tissue obtained in diverse and morally complex ways. A major challenge for the ethics of stem cell science is therefore to address the ethical issues at play within the evolving tissue economies.

Competing interests: None.

\section{REFERENCES}

1. Robertson JA. Human embryonic stem cell research: ethical and legal issues: Nat Rev Genet 2001;2:74-8

2. Chan S, Harris J. Adam's fibroblast? The (pluri)potential of iPCs [editorial]. J Med Ethics 2008;34:64-6.

3. Holm S, Takala T. High hopes and automatic escalators: a critique of some new arguments in bioethics. J Med Ethics 2007;33:1-4.

4. Braude $\mathbf{P}$, Minger S, Warwick R. Stem cell therapy: hope or hype? BMJ 2005;330:1159-60.

5. Sample I. Has stem cell research been over-hyped? The Guardian 8 September 2005.

6. Bostrom N. Human genetic enhancements: a transhumanist perspective. J Value Inquiry 2003;37:493-506.

7. Thompson C. Making parents: the ontological choreography of reproductive technologies. Cambridge, Massachusetts: MIT Press, 2005.

8. Brown N, Kraft A, Martin P. The promissory pasts of blood stem cells. BioSocieties 2006;1:329-48.

9. Tallis R. Hippocratic oaths. London: Atlantic Books, 2004

10. Wooton D. Bad medicine: doctors doing harm since Hippocrates. Oxford: Oxford University Press, 2006.

11. Bergan A. Ancient myth, modern reality: a brief history of transplantation. J Biocommun 1997;24:2-9.

12. Buckner CD. Autologous bone marrow transplants to hematopoietic stem cell support with peripheral blood stem cells: a historical perspective. J Hematother 1999;8:233-6.

13. Goker H, Haznedaroglu IC, Chao NJ. Acute graft-vs-host disease: pathobiology and management. Exp Hematol 2001;29:259-77.

14. Sheldon S, Wilkinson S. Should selecting saviour siblings be banned? J Med Ethics 2004;30:533-7.

15. Anon. Inside the Ethics Committee. Saviour siblings, BBC Radio 4, 6 Aug 2008. http:// www.bbc.co.uk/radio4/science/ethicscommittee_20080806.shtml laccessed 18 October 2008).

16. Holm S. The ethical case against stem cell research. Camb 0 Healthc Ethics 2003;12:372-83.

17. Wainwright SP, Williams C, Michael M, et al. Ethical boundary-work in the embryonic stem cell laboratory. Sociol Health IIIn 2006 28:6:732-48.

18. Woods S, Taylor K. Ethical and governance challenges in human foetal tissue research. Clinical Ethics 2008;3:14-9.

19. Haimes E, Porz R, Scull J, et al. "So what is an embryo?" A comparative study of the views of those asked to donate embryos for hESC research in the UK and Switzerland. New Genet Soc 2008 27:2:113-26.

20. McLaughlin L. The pill, John Rock and the church. Boston: Little, Brown, 1982

21. Moore $v$ Regents of the University of California. 793, P.2d 479 (Cal 1990).

22. Pfeffer N, Kent J. Framing women, framing fetuses: how Britain regulated arrangements for the collection and use of aborted fetuses in stem cell research and therapies. BioSocieties 2007;2:429-47.

23. Pfeffer N. What British women say matters to them about donating an aborted fetus to stem cell research: a focus group study. Soc Sci Med 2008;66:2544-54.

24. Department of Health. Review of the guidance on the research use of fetuses and fetal tissues. London: HMSO, 1989:762.

25. Franklin S. Embryonic economies: the double reproductive value of stem cells. BioSocieties 2006 1:71-90.

26. Holm S. Who should control the use of human embryonic stem cell research? $J$ Bioeth Inq 2006 3;1-2:55-68.

27. Jasanoff S. Designs on nature. Princeton: Princeton University Press, 2005

28. House of Commons Science and Technology Committee. Government proposals for the regulation of hybrid and chimera embryos. Fifth report of session 2006-07 HC 272-1. London: Stationery Office, 2007.

29. Scottish Council on Human Bioethics. Embryonic, fetal and post-natal animalhuman mixtures: an ethical discussion. Edinburgh: SCHB, 2006 http://www.schb.org. uk/ (Search through Publications, Animal-human combinations). (Accessed 27 October 2008). 